\title{
SPODOBASE : an EST database for the lepidopteran crop pest
} Spodoptera

Vincent Nègre ${ }^{1,6}$, Thierry Hôtelier ${ }^{1}$, Anne-Nathalie Volkoff², Sylvie Gimenez ${ }^{2}$, François Cousserans ${ }^{2}$, Kazuei Mita ${ }^{4}$, Xavier Sabau ${ }^{5}$, Janick Rocher ${ }^{2,7}$, Miguel López-Ferber ${ }^{2}$, Emmanuelle d'Alençon ${ }^{2}$, Pascaline Audant ${ }^{3}$, Cécile Sabourault ${ }^{3}$, Vincent Bidegainberry ${ }^{3}$, Frédérique Hilliou ${ }^{3}$ and Philippe Fournier*2

Address: ${ }^{1}$ Unité Informatique de Centre, INRA-AgroM, 2 place Viala, 34060 Montpellier Cedex 2, France, ${ }^{2}$ Unité Biologie Intégrative et Virologie des Insectes, UMR1231, Université UMII, Bât. 24, cc101, place Eugène Bataillon, 34095 Montpellier Cedex 5, France, ${ }^{3}$ Unité Résistance des Organismes aux Stress Environnementaux, UMR1112, INRA, 400 route des Chappes, BP167, 06903 Sophia-Antipolis Cedex, France, ${ }^{4}$ Insect Genome Laboratory, National Institute of Agrobiological Sciences, 2-1-2 Kannondai, Tsukuba, Ibaraki 305-8602, Japan, 5Unité Polymorphisme d'Intérêt Agronomique, Dép. AMIS, CIRAD, TA40/03, avenue d'Agropolis, 34398 Montpellier Cedex 5, France, 6 EMI 0229 INSERM, CRLC Val d'Aurelle, 34298 Montpellier Cedex 5, France and 7Ecole des Mines, Départ. LGEI, 6 av. Clavières, 30319 Alès Cedex, France

Email: Vincent Nègre - Vincent.Negre@igh.cnrs.fr; Thierry Hôtelier - hotelier@ensam.inra.fr; Anne-Nathalie Volkoff - volkoff@ensam.inra.fr; Sylvie Gimenez - gimenezs@ensam.inra.fr; François Cousserans - coussera@ensam.inra.fr; Kazuei Mita - kmita@nias.affrc.go.jp; Xavier Sabau - xavier.sabau@cirad.fr; Janick Rocher - jrocher@ensam.inra.fr; Miguel López-Ferber - Miguel.Lopez-Ferber@ema.fr; Emmanuelle d'Alençon - alencon@ensam.inra.fr; Pascaline Audant - Pascaline.Audant@antibes.inra.fr; Cécile Sabourault - sabourau@antibes.inra.fr; Vincent Bidegainberry - bidegainberry@antibes.inra.fr; Frédérique Hilliou - Frederique.Hilliou@antibes.inra.fr; Philippe Fournier* - fourniep@ensam.inra.fr * Corresponding author

Published: 23 June 2006

BMC Bioinformatics 2006, 7:322 doi:10.1 |86/147|-2105-7-322
Received: 21 December 2005

Accepted: 23 June 2006

This article is available from: http://www.biomedcentral.com//47I-2/05/7/322

(C) 2006 Nègre et al; licensee BioMed Central Ltd.

This is an Open Access article distributed under the terms of the Creative Commons Attribution License (http://creativecommons.org/licenses/by/2.0), which permits unrestricted use, distribution, and reproduction in any medium, provided the original work is properly cited.

\begin{abstract}
Background: The Lepidoptera Spodoptera frugiperda is a pest which causes widespread economic damage on a variety of crop plants. It is also well known through its famous Sf9 cell line which is used for numerous heterologous protein productions. Species of the Spodoptera genus are used as model for pesticide resistance and to study virus host interactions. A genomic approach is now a critical step for further new developments in biology and pathology of these insects, and the results of ESTs sequencing efforts need to be structured into databases providing an integrated set of tools and informations.
\end{abstract}

Description: The ESTs from five independent CDNA libraries, prepared from three different S. frugiperda tissues (hemocytes, midgut and fat body) and from the Sfg cell line, are deposited in the database. These tissues were chosen because of their importance in biological processes such as immune response, development and plant/insect interaction. So far, the SPODOBASE contains 29,325 ESTs, which are cleaned and clustered into non-redundant sets (2294 clusters and 6103 singletons). The SPODOBASE is constructed in such a way that other ESTs from S. frugiperda or other species may be added. User can retrieve information using text searches, pre-formatted queries, query assistant or blast searches. Annotation is provided against NCBI, UNIPROT or Bombyx mori ESTs databases, and with GO-Slim vocabulary.

Conclusion: The SPODOBASE database provides integrated access to expressed sequence tags (EST) from the lepidopteran insect Spodoptera frugiperda. It is a publicly available structured database with insect pest sequences which will allow identification of a number of genes and comprehensive cloning of gene families of interest for scientific community. SPODOBASE is available from URL: http://bioweb.ensam.inra.fr/spodobase 


\section{Background}

Lepidoptera represent a diverse and important group of agricultural insect pests that cause widespread economic damage on food and fiber crop plants, fruit trees, forests, and stored grains. They are also important indicators of ecosystem diversity and health. Moreover, lepidopteran insects display experimental advantages such as their large body size, accessible genetics, and extreme diversity. They show a large spectrum of interactions with plants and with numerous parasites or pathogens. Among Lepidoptera, the genus Spodoptera is largely studied due to its wide geographical distribution area. Indeed Spodoptera species are scattered over all continents. Presence of $S$. frugiperda in the American continent and in the Caribbean area has been studied in detail $[1,2]$. S. frugiperda larvae cause severe damage on many cultivated crops including corn, rice and maize. S. littoralis is reported to cause damages in Mediterranean and African subtropical regions as well as in China whereas S. litura is found in India, Indonesia and Australia. In addition to being important agricultural pests these noctuids are biological models studied for several purposes. For example,S. frugiperda is well known through its famous Sf21 cell line and its Sf9 subclone [3] which is used for numerous heterologous protein productions. $S$. frugiperda is also used to study pesticide resistance $[4,5]$ and baculovirus host interaction [6], whereas S. littoralis is a model species to study pheromone regulations [7-9] or densovirus pathogenicity [10].

The development of new methods of insect pest management is an important challenge for world economy and health and it will be facilitated by a better knowledge of lepidopteran crop pest genomics. Indeed, genome information provides powerful tools for understanding biological mechanisms and functions and is essential for biology, medical science, and agriculture.

Recent years have shown a tremendous development of genome projects of various species, in particular for insects. Among model organisms, genome sequences have been completed in Drosophila melanogaster [11], the malaria mosquito, Anopheles gambiae [12], the honeybee Apis mellifera [13] and the silkworm Bombyx mori [14,15]. In the year 2002 an International Lepidoptera Genome Consortium was created, which gathers the cooperative efforts of various laboratories in the world on genomic and transcriptomic studies on insects of scientific and economic importance [16]. The project is organized in a "Bombyx - Plus" scheme, where Bombyx mori represents the core node of the knowledge both in terms of genetics, physiology, and EST sequencing [17]. Around this model, the genomic study of a variety of pests of agronomical importance has been encouraged, as functional genomics analysis were still limited by the lack of relevant genome databases for gene identification. Several EST sequencing projects have already begun, but the results of only a few are available, as for example on Choristoneura fumiferana [18], Helicoverpa armigera [19], Plutella xylostella or Manduca sexta [20]. Some other butterflies are also investigated [21]. We have developed resources for Spodoptera frugiperda, for which we have created a genomic BAC library [22] and a set of Expressed Sequence Tags (ESTs) from the well known Sf9 cell line [23]. Other labs have also reported the development of ESTs collections (Rollie J. Clem, Kansas State University, pers. comm.).

Here we present the database, named SPODOBASE, which provides integrated access to expressed sequence tags (EST) from $S$. frugiperda. The SPODOBASE currently contains 29,325 sequences from various organs (Sf) cell line, hemocytes, midgut and fat body tissues). The EST sequences were cleaned and clustered into non-redundant sets (2294 clusters and 6103 singletons). User can retrieve information using text searches, pre-formatted queries, query assistant or blast searches.

This database will enable future functional genomics studies of a variety of biological processes such as immunity, endocrinology, reproduction or behavior. Since several physiological processes have been shown to be conserved through evolution, their study in lepidopteran models will help to further elucidate the function of homologous genes and will provide complements to the model insects Drosophila and Anopheles. For example these two model insects lack the receptors for the largely used Bacillus thuringiensis toxin as well as for most of the chemical pesticides (acetyl cholinesterase type). One can predict that analysis of the lepidopteran crop pests will contribute to sustainable agriculture, protection of the environment and maintenance of biodiversity.

\section{Construction and content}

\section{Construction of cDNA libraries and sequencing}

Four directional cDNA libraries were generated for Spodoptera frugiperda larvae. A Sf9 cell line library has been previously constructed and described [23]. To generate the new libraries, different tissues of last larval instars, circulating hemocytes, fat body and midgut, were collected directly in TRIZOL reagent (InVitroGen). Extracted total RNAs were reverse transcribed using the SMART cDNA library Construction Kit (Clontech) according to manufacturer instructions. The library was built in $\lambda$ Triplex 2 . From the phages, excision and circularization of pTriplEx plasmid was heat-induced at loxp sites in order to generate a plasmid library to be sequenced. The clones were robotpicked from agarose plates (CIRAD platform, Montpellier) and stored in 20\% glycerol LB medium in 96-wells plates. A total of 72, 126 and 191 plates were seeded for the hemocyte $(\mathrm{H})$, fat body $(\mathrm{F})$ and midgut $(\mathrm{M})$ libraries, respectively. 
The 37,344 bacterial clones were then spotted on high density Nylon membranes and hybridized with an oligonucleotide probe encompassing the multiple cloning site in order to detect empty plasmid clones. Hybridization was conducted at high stringency and allowed the elimination of around $30 \%$ clones in the different libraries. After colony picking, a limited sequencing test on 1900 clones from the 3 libraries revealed that the percentage of clones without insert was around 9\%, showing an effective but non total rearrangement.

A second hybridization was performed with a probe consisting of a mixture of $40 \mathrm{cDNAs}$, in order to detect clones corresponding to cDNAs that were abundantly represented within the previously analyzed Sf9 library. We were expecting to increase coverage and decrease the number of sequences corresponding to known housekeeping genes. This hybridization leaded to the elimination of $0.7 \%, 1.9$ $\%$ and $4.4 \%$ of the clones in F, $\mathrm{M}$ and $\mathrm{H}$ libraries, respectively. We observed (See Table A) that the abundance of these clones was significantly reduced by this procedure, as their percentage in the library decreased from $36 \%$ in the initial Sf9 library to $11 \%$ in the four tissues libraries. Elimination was not total, probably because the complex probe does not detect easily all of the 40 genes, but it was still useful to avoid useless sequencing.

To assess inserts size, DNA was extracted from 96, 48 and 48 clones from the $\mathrm{H}, \mathrm{F}$ and $\mathrm{M}$ libraries, respectively using the Qiagen DNA extraction kit. Inserts were amplified by PCR using primers flanking the insert cloning sites and their size was controlled by agarose gel electrophoresis. We found an average size of 1.1, 1.0 and $0.9 \mathrm{~kb}$ for the $S$. frugiperda cDNAs from the $\mathrm{H}, \mathrm{F}$ and $\mathrm{M}$ libraries, respectively.

The libraries were thus re-assorted in a total of 55 plates for the hemocyte library, 87 plates for the fat body library and 149 plates for the midgut library, stored in 5\% glycerol 2YT medium, in duplicate. From those, 5184 (54 plates), 6048 (63 plates) and 5952 (62 plates) clones were subjected to sequencing for hemocyte, fat body and midgut libraries, respectively. The plasmid DNAs were extracted from overnight grown bacterial cultures using an automated plasmid isolation machine BIO ROBOT 8000 (Qiagen). The cDNAs were sequenced using ABI PRISM BigDye Terminator Cycle Sequencing Ready Reaction kits on an ABI PRISM 3700 DNA Analyzer (Applied Biosystems) in Insect Genome Laboratory of National Institute of Agrobiological Sciences (NIAS, Japan). All clones were sequenced from both $5^{\prime}$ and $3^{\prime}$ extremities using forward and reverse primers located in the pTriplex vector, in a region flanking the insert. We thus obtained a total of $10,368,12,096$ and 11,904 sequences for hemocytes, fat body and midgut respectively.
A second midgut cDNA library was made from pooled mRNAs extracted from midguts of 3rd instar larvae fed on artificial diet supplemented with various natural products and xenobiotics. This library generated a set of 2,688 sequences.

\section{The SPODOBASE pipeline}

Once the sequences established, they were analyzed and processed according to the flow chart depicted in Figure 1. The pipeline developed for EST analysis was divided into three steps: EST quality control, clustering and annotations.

\section{2-I EST quality control}

The sequences were given a unique ID consisting of a prefix including the species (Sf), 1 digit for the library number, the tissue origin ( $\mathrm{H}, \mathrm{M}, \mathrm{F}$ or SF9L), 5 digits for clone number, 1 for sequencing direction and 1 for walking number. Sequences were then subjected to quality checking. Base calling step was performed using the Phred program $[24,25]$. Low quality bases (phred score $<10$; this quite permissive score was chosen due to the low quality of some of the EST sequences) were masked and sequences with more than $30 \% \mathrm{n}$-content were removed. The vector sequences were detected and removed. For this, we used BLASTN [26] with the following parameters (-q 5 -G 3 -E 3 -F "m D" -e 700 -Y 1.75e12). Due to their short length (less than $20 \mathrm{bp}$ ), the adaptor sequences were detected with an exact and more sensitive local alignment algorithm (Miller-Myers algorithm) and then eliminated. The regions of the sequences that contained more than 15 $\mathrm{N}$ 's on a 20 bases window in the first/last quarters of the sequence were removed on both ends. The sequences with nucleotide stretches, indicators of sequences of bad quality, were also removed. Lastly, the cleaned sequences shorter than $100 \mathrm{bp}$ were eliminated. After the cleaning process, we obtained a total of 23,503 sequences, representing $63 \%$ of the initial $37,056 \mathrm{EST}$ sequences. With the 5822 EST already available from the Sf9L library, SPODOBASE contains a total of 29,325 ESTs, which are in majority 500-600 bp long. The distribution of EST sequences according to tissue origin is given in Table 1 . Sequencing was conducted in both directions for all ESTs coming from tissues (Sf9 clones had only be 5 ' sequenced), but both sequences were not always retained after quality control, especially at the 3 ' end. The number of clones with available $5^{\prime}$ only, $3^{\prime}$ only or both sequences is given on Table 1, where one can see that 20163 clones have produced a readable sequence.

\section{2-2 EST clustering}

All the 29,325 cleaned EST sequences were then subjected to clustering using the TIGR software TGI Clustering tool (TGICL) [27]. The clustering was performed by a modified version of NCBI's megablast. EST sequences were assigned 


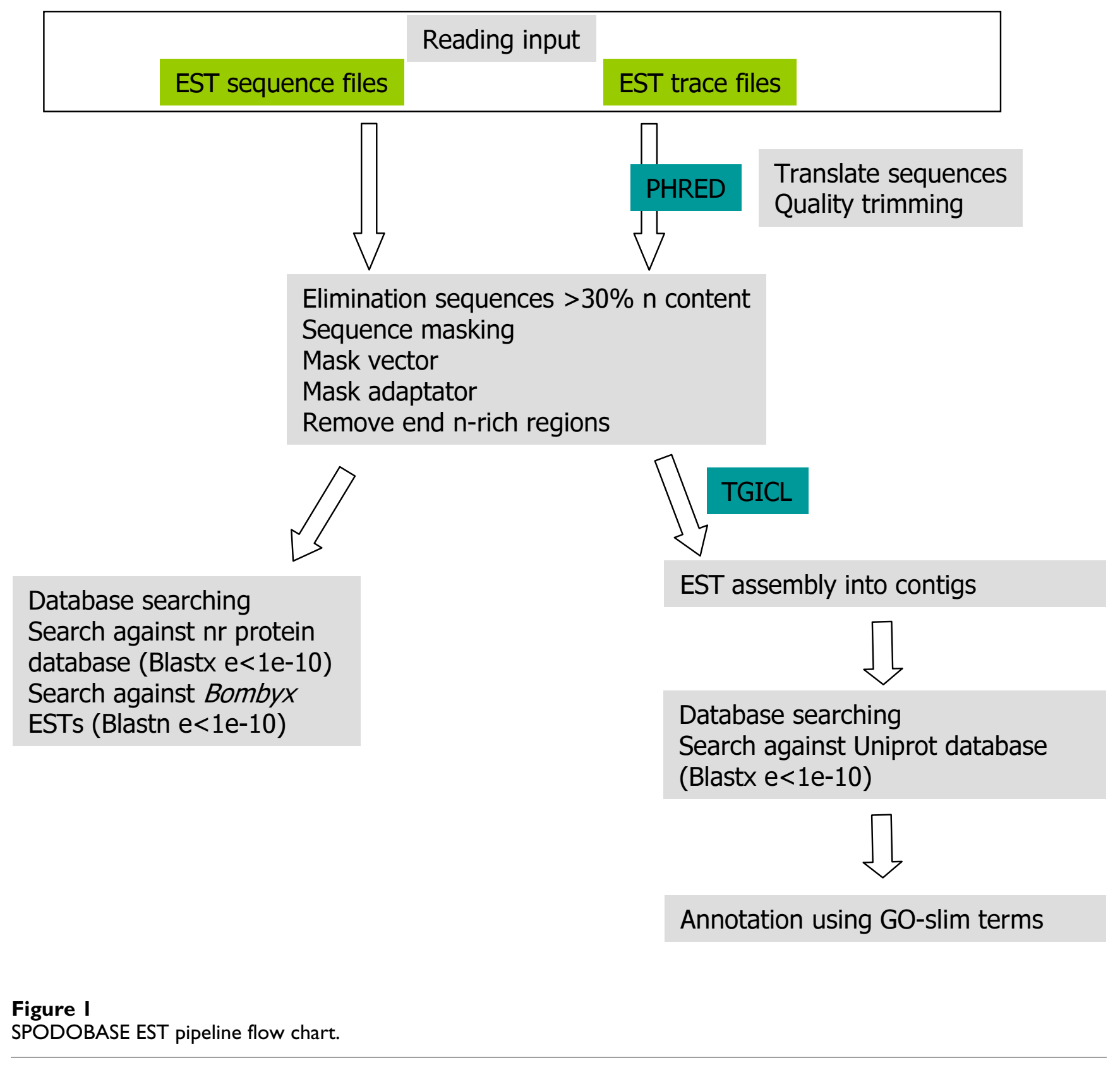

to clusters based on identity: the clustering parameters were $98 \%$ minimum percent identity for overlaps, for a minimum overlap length of $40 \mathrm{nt}$ and a maximum length of unmatched overhangs of $20 \mathrm{nt}$. The cluster names corresponded to the name of the first EST sequence assigned to the cluster. Thus, each cluster name will be maintained as additional ESTs are added to the database. After analysis, the 29,325 cleaned EST sequences were distributed among 2294 clusters and 6103 singletons. Most of the clusters $(2141 ; 93 \%)$ contained 2 to 25 ESTs (Figure 2). In this step, $5^{\prime}$ and $3^{\prime}$ sequences are treated as independent data, so that sequences coming from the same clone may belong to two different clusters. This allows to control if a clone is not colinear to the genome (due to cloning artifact), or if the encoded gene contains similarities with two different genes. We then examined the clone origin of clusters and singletons and were able to deduce from these data a set of 5186 unigenes. As Spodoptera has a genome coding capacity (genome size $407 \mathrm{Mb}$, see ref. 22 comparable or slightly smaller than that of Bombyx mori 


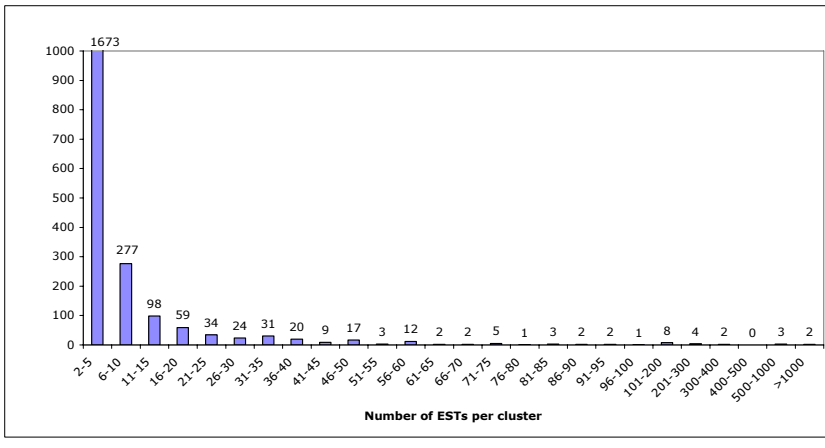

Figure 2

Distribution of the number of ESTs per cluster for the 2294 clusters. The number of EST is given for each class of abundance $(2-5,6-10,11-15$, etc).

(genome size $514 \mathrm{Mb}$ for an estimated gene count of around 18,500; see refs. $[14,15]]$, one can assume that the 5186 Spodoptera unigene collection described here represents at least $35 \%$ of potential total gene number.

\section{2-3 EST assembling}

Sequences from each cluster were assembled into consensus sequences called contigs using the CAP3 assembly program available in TGICL. By doing that, we found 97 clusters $(4 \%)$ that were separated in more than one contigs (Table 2) leading to a final number of 2436 contigs instead of the 2294 clusters described above. This discrepancy can be explained by small differences in the EST sequences probably due to transcript diversity (mutations, deletions). Note that sequences from a cluster containing only one sequence are called singletons.

\section{2-4 EST annotation}

To identify similarities with known proteins, the sequences were searched using the BLASTX algorithm against a local non-redundant protein database (NR,
NCBI, release 151.0, $1^{\text {st }}$ February 2006) with a cut-off Evalue of $1 \mathrm{e}-10$. A total of 18,736 (64\%) sequences were found to share significant similarity with a protein sequence deposited in the NCBI non-redundant database.

As genome data (including ESTs) of Bombyx mori are the most important among Lepidoptera, it represents a model organism within this order. We thus subjected the EST sequences to TBLASTX searches against $116,541 \mathrm{~B}$. mori sequences deposited in the NCBI dbEST database with a cut-off E-value of 1e-10. A total of 21,185 (72\%) sequences were found to share significant similarities with silkworm EST sequences.

Thus, $24 \%$ (8141) of the $S$. frugiperda ESTs do not have a match in BLAST searches against neither NCBI nr nor Bombyx mori databases. To identify those that did not match because they may correspond to untranslated regions, a search for predicted coding regions was performed with the software ESTScan [28]. Indeed, from these 8141 sequences, we identified 3624 sequences ( 44.5 $\%)$ lacking predicted coding regions. Consequently, only $15 \%$ of all sequences should be considered as new sequences. At this stage it should also be emphasized that $B$. mori ESTs database do not represent the total number of putative silkworm genes, thus the TBLASTX should be conducted against whole $B$. mori genome when it will be annotated. This observation may also be correlated with the phylogenetic distance which separates the two species. Indeed, although the monophyletic origin of Lepidoptera is well admitted [29], Bombycoidea and Noctuidea are two well distinct super families among this order, separated by probably more than 60 million years [30-32].

We also compared the 2436 contigs and the 6103 singletons to the Uniprot [33] protein database (release 6.0, September 2005) using the BLASTX program with a $1 \mathrm{e}-10$ cut-off. We found 1178 contigs (48\%) and 1809 singletons $(30 \%)$ that showed a significant similarity with a Uniprot entry.

Table I: Tissue distribution of the number of clones having produced either 5' or 3' end sequencing or both, and subsequent EST numbers in SPODOBASE.

\begin{tabular}{lcccc}
\hline & clones with available & Both 5' \& 3' seq. & Total nb of ESTs \\
\hline Sf9L, Sf9 cell Line & 5822 & 3' seq. only & 0 & 5822 \\
SfIF, Fat body & 459 & 292 & 3210 & 7171 \\
SfIH, Hemocytes & 491 & 357 & 2576 & 6000 \\
SfIM, Midgut & 436 & 425 & 2644 & 6149 \\
Sf2M, Midgut & 2663 & 56 & 732 & 4183 \\
Total per category & 9871 & 1130 & 9162 & 29325 \\
\hline Total nb of clones & & 20163 & & \\
\hline
\end{tabular}


Table 2: Distribution of the number of contigs among the clusters. The final number of contigs is given.

\begin{tabular}{|c|c|c|c|}
\hline & nb of clusters & contigs/cluster & nb of contigs \\
\hline & 2197 & 1 & 2197 \\
\hline & 80 & 2 & 160 \\
\hline & 7 & 3 & 21 \\
\hline & 5 & 4 & 20 \\
\hline & 2 & 6 & 12 \\
\hline & I & 8 & 8 \\
\hline & I & 9 & 9 \\
\hline & 1 & 10 & 10 \\
\hline total & 2294 & & 2437 \\
\hline
\end{tabular}

2-5- GO assignment of the EST sequences in the SPODOBASE To define the function of the contigs and singletons present in the SPODOBASE, we used the Gene Ontology (GO) controlled vocabulary [34], and more particularly GOSlim, a subset of GO terms, which provides a higher level of annotations and allows a more global view of the dataset. To this end, we searched for the GOSlim terms (provided by GOA [35] released on January 2006) associated with the 1178 contigs and 1809 singletons that showed a significant similarity with a Uniprot entry. These identifiers were further used to select the sequences to be printed on a Spodoptera DNA microarray (R. Feyereisen, pers. comm.).

\section{2-6- Software}

The database is based on the AceDB database management system version [36], originally created for the worm Caenorhabditis elegans, and used by many databases: WormBase [37], crop-related databases available from the UK Crop Plant Bioinformatics Network WWW site [38], MagnaportheDB [39], ESTHER [40], ParaDB [41], TropGene [42], etc. This is an object-oriented system capable of storing and retrieving complex biological information. The Web server is an Apache Web server version running on Red Hat Linux version. The Web consultation interface is implemented with Perl/CGI scripts, using modules of the AcePerl Application Programming Interface (API) and the AceBrowser generic web interface [43]. The EST pipeline was created with Perl programming language and Bioperl libraries and used additional programs (PHRED for sequence quality control, BLAST for contaminant detection and annotation step, TGICL for clustering and assembling).

\section{Utility and discussion I- User interface}

For each sequence, series of information are available including the direction of sequencing, the existence of the other direction sequence, the relation to an existing cluster, the 10 best hits of BLASTX against NCBI and Bombyx EST database, and the library where the sequence was found. For each cluster, the software displays the distribution of sequences among the different tissue libraries, and gives the list of sequences belonging to the cluster; it offers the possibility to visualize their alignment and to download the FASTA file comprising all of them. The 10 best hits of BLASTX against Uniprot and G0 annotations are available for each contig and singleton. Users can query database in several ways. Information can be retrieved according to text search or using a query assistant.

\section{I-I- Classical AceDB queries}

User can query database with AceDB data queries (Class, Text and AceDB queries). Class query allows the user to retrieve objects by class, with the possibility of restricting the search to names that match a pattern. Text query is a keyword-based search on all the data. AceDB query uses the Ace Query Language (AQL), which was created to formulate complex queries based on several criteria. In order to create an AQL request, the user must know the structure of the object model and learn a specific syntax. However some examples of classical questions written in AQL can be found at the AQLquery top page.

\section{I-2- Query assistant}

To help the user for retrieval, we implemented the QueryBuilder tool [43]. This is a step-by-step graphic interface to formulate Ace queries. Five initial choices are proposed, concerning the clusters, the singletons, the libraries, the contigs or the sequences themselves. After this, the retrieval can be directed within a specific field and the chain of characters or numbers to be found are used in combination with the classical Boolean operators.

\section{I-3- BLAST search}

Users can search for similarities between their own sequences using BLASTN, TBLASTN or TBLASTX searches against the whole set of $S$. frugiperda EST sequences.

\section{2- Intended uses}

The database provides an overview of $S$. frugiperda transcripts. One of the major interests of the SPODOBASE 
Table A:

\begin{tabular}{|c|c|c|c|c|c|c|c|}
\hline clone/sequence & cluster & ID & Sf9L (clones) & $\%$ & tissue(clones) & $\%$ & total (clone) \\
\hline SF9LQ2237 & SF9L0000I & cytochrome b & 142 & 2,4 & 145 & 1,0 & 287 \\
\hline SF9L0I474 & SF9L00002 & ribosomal protein L8 & 27 & 0,5 & 21 & 0,1 & 48 \\
\hline SF9L022I 5 & SF9L00003 & ribosomal protein $\$ 23$ & 21 & 0,4 & 6 & 0,0 & 27 \\
\hline SF9L0I479 & SF9L00004 & cytochrome c oxydase subunit III & 426 & 7,3 & 607 & 4,2 & 1033 \\
\hline SF9L02449 & SF9L0045I & ribosomal protein LI4 & 30 & 0,5 & 8 & 0,1 & 38 \\
\hline SF9L0I576 & SF9L00008 & ribosomal protein $\mathrm{L} 23$ & 178 & 3,1 & 20 & 0,1 & 198 \\
\hline SF9L0I837 & SF9L00009 & ribosomal protein SII & 42 & 0,7 & 16 & 0,1 & 58 \\
\hline SF9L0I752 & SF9L000I 4 & ribosomal protein L35A & 76 & 1,3 & 7 & 0,0 & 83 \\
\hline SF9L0I773 & SF9L000I7 & ribosomal protein LIOA & 29 & 0,5 & 6 & 0,0 & 35 \\
\hline SF9L0I547 & SF9L00018 & ribosomal protein L24 & 32 & 0,5 & 10 & 0,1 & 42 \\
\hline SF9L03436 & SF9L00024 & ribosomal protein SI4 & 26 & 0,4 & 17 & 0,1 & 43 \\
\hline SF9L0I 952 & SF9L00027 & cofilin & 46 & 0,8 & 27 & 0,2 & 73 \\
\hline SF9L0I583 & SF9L00035 & ribosomal protein L22 & 97 & 1,7 & 11 & 0,1 & 108 \\
\hline SF9L0I582 & SF9L00037 & ribosomal protein L37A & 49 & 0,8 & 6 & 0,0 & 55 \\
\hline SF9L03736 & SF9L00045 & ribosomal protein $\mathrm{S8}$ & 38 & 0,7 & 9 & 0,1 & 47 \\
\hline SF9L0216I & SF9L00047 & NS & 33 & 0,6 & 16 & 0,1 & 49 \\
\hline SF9L0I896 & SF9L00052 & ribosomal protein L32 & 31 & 0,5 & 2 & 0,0 & 33 \\
\hline SF9L0I859 & SF9L00055 & ribosomal protein SI0 & 28 & 0,5 & 12 & 0,1 & 40 \\
\hline SF9L02679 & SF9L00056 & ribosomal protein LI3A & 25 & 0,4 & 15 & 0,1 & 40 \\
\hline SF9L0I559 & SF9L00084 & cytochrome c oxydase subunit II & 146 & 2,5 & 511 & 3,6 & 657 \\
\hline SF9LOII5I & SF9L00094 & ribosomal protein L37 & 24 & 0,4 & 6 & 0,0 & 30 \\
\hline SF9L02183 & SF9L00III & ribosomal protein \$26 & 17 & 0,3 & 6 & 0,0 & 23 \\
\hline SF9L0I846 & SF9L00II4 & ribosomal protein $\mathrm{S} 3 \mathrm{~A}$ & 40 & 0,7 & 15 & 0,1 & 55 \\
\hline SF9L0I7I2 & SF9L00II8 & ribosomal protein L39 & 22 & 0,4 & 11 & 0,1 & 33 \\
\hline SF9L02623 & SF9L00I 22 & ribosomal protein $\$ 25$ & 19 & 0,3 & 4 & 0,0 & 23 \\
\hline SF9L02635 & SF9L00I43 & ribosomal protein $\mathrm{L} 28$ & 49 & 0,8 & I & 0,0 & 50 \\
\hline SF9L0I443 & SF9L00I44 & ribosomal protein $\mathrm{SI} 7$ & 40 & 0,7 & 8 & 0,1 & 48 \\
\hline SF9L0I7I4 & SF9L00I74 & ribosomal protein L3I & 36 & 0,6 & 5 & 0,0 & 41 \\
\hline SF9L02426 & SF9L00I76 & ribosomal protein $\mathrm{SI} 3$ & 32 & 0,5 & 4 & 0,0 & 36 \\
\hline SF9L03724 & SF9L00197 & ribosomal protein $\$ 4$ & 42 & 0,7 & 12 & 0,1 & 54 \\
\hline SF9LOI028 & SF9L00240 & ribosomal protein $\mathrm{L} 27$ & 23 & 0,4 & 5 & 0,0 & 28 \\
\hline SF9LOI 232 & SF9L00323 & ribosomal protein $\mathrm{L} 40$ & 35 & 0,6 & 15 & 0,1 & 50 \\
\hline SF9L0I723 & SF9L00334 & ribosomal protein SI 2 & 32 & 0,5 & 3 & 0,0 & 35 \\
\hline SF9L0I766 & SF9L00336 & ribosomal protein L36A & 18 & 0,3 & 9 & 0,1 & 27 \\
\hline SF9L0I498 & SF9L00385 & ribosomal protein S20 & 27 & 0,5 & 2 & 0,0 & 29 \\
\hline SF9L02368 & SF9L0042I & ribosomal protein S24 & 21 & 0,4 & 5 & 0,0 & 26 \\
\hline SF9L03196 & SF9L00574 & ribosomal protein L2I & 17 & 0,3 & 6 & 0,0 & 23 \\
\hline SF9L0I548 & SF9L00632 & ribosomal protein L27A & 62 & $\mathrm{I}, \mathrm{I}$ & 10 & 0,1 & 72 \\
\hline SF9L02262 & SF9L00705 & ribosomal protein LI3 & 25 & 0,4 & 12 & 0,1 & 37 \\
\hline \multirow[t]{3}{*}{ SF9L02428 } & SF9L0I994 & ribosomal protein S3 & 23 & 0,4 & 7 & 0,0 & 30 \\
\hline & & TOTAL & 2126 & $S=5822$ & 1618 & $S=14382$ & 3744 \\
\hline & & $\%$ & 36,5 & & 11,3 & & \\
\hline
\end{tabular}

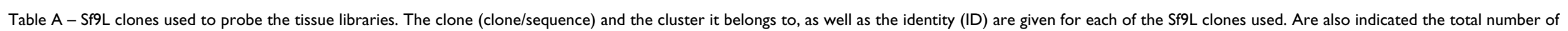
clones found in the Sf9L and in the 3 tissues libraries (clones) and their percentage (\%) compared to the total number of Sf9L clones and the 4 tissue libraries in SPODOBASE. 
consists in the large number of sequences and the existence of 5 different tissues cDNA libraries. The database can be used, among other applications, for functional genomics (primer design for micro-array analysis), to identify the genes expressed predominantly in a given tissue, and to compare genes between different species. On the basis of extensive sequence-based analysis of relationships among noctuids, it has been recently shown [44] that Spodoptera is relatively close to a group of species called the "pest clade" and including Heliothinae and Noctuinae s. $l$. Actually SPODOBASE is constructed in such a way that it can welcome large numbers of additional sequences from other different tissues of $S$. frugiperda, as well as from other Spodoptera species. The implementation of $S$. littoralis ESTs is already programmed for a near future.

\section{Conclusion}

The SPODOBASE represent a major contribution to the genomics of Spodoptera frugiperda. Together with BAC library, existence of various cell lines and expression systems, this makes of $S$. frugiperda of the most advanced models among agricultural pests in terms of genomic resources. SPODOBASE contains EST sequences that are cleaned, clusterized and annotated. These informations are available to serve insect research community, provide better understanding of the Lepidoptera physiology and identify new molecules targeted against Lepidoptera pests that could be used as safe biopesticides for sustainable agriculture.

\section{Availability and requirements}

The database is publicly available at the following URL:http://bioweb.ensam.inra.fr/spodobase. All sequences could be downloaded from SPODOBASE (see Download section). They have also been deposited in dbEST database (accession numbers for midgut library: DV075863 to DV080045 and DY786624 to DY7927772; fat body library: DY773453 to DY780623; hemocytes: DY773453 to DY780623; Sf9 cell line library: DY895775 to DY901596).

\section{Authors' contributions}

$\mathrm{VN}, \mathrm{TH}, \mathrm{MLF}$ and FC constructed the database format and arranged the pipeline of algorithms that sequences should go through. VN and TH developed the user interface. SG, $\mathrm{KM}, \mathrm{XS}, \mathrm{JR}, \mathrm{EdA}, \mathrm{PA}, \mathrm{CS}, \mathrm{VB}$ and $\mathrm{FH}$ were involved in tissue mRNA isolation, library construction, replicating and storage of the clones, and ESTs sequencing. ANV analyzed the clusters, the GO classification, and wrote the paper initial draft. PF conceived and coordinated the study as responsible of the genomic Spodoptera program, and helped VN to draft the manuscript. All others agreed with the manuscript.

\section{Abbreviations \\ bp: base pairs}

nt: nucleotide

EST: Expressed Sequence Tags

cDNA: copy DNA

GO: Gene Ontology

\section{Acknowledgements}

In additional to annual financial support from INRA (SPE department) and University of Montpellier, this work was specifically funded by grants of the Bureau des Ressources Génétiques, of the Ministère de la Recherche (Programme Séquençage à Grande Echelle), and by the INRA programme called AIP-Séquençage. We gratefully thank René Feyereisen (INRA Sophia-Antipolis) for his help in the coordination of the French Lep genome programme and for involvement of several contributors from his lab. We also thank Cyril Berthenet and Ned Lamb (IGH, CNRS) for their technical support.

\section{References}

I. Molina-Ochoa J, Carpenter JE, Heinrichs EA, Foster JE: Parasitoids and parasites of Spodoptera frugiperda (Lepidoptera: Noctuidae) in the Americas and Caribbean Basin: an inventory. Florida Entomologist 2003, 86:254-289.

2. Molina-Ochoa J, Lezama-Gutierrez R, Gonzalez-Ramirez M, LopezEdwards M, Rodriguez-Vega MA, Arceo-Palacios F: Pathogens and parasitic nematodes associated with populations of fall armyworm (Lepidoptera: Noctuidae) larvae in Mexico. Florida Entomologist 2003, 86:244-253.

3. Vaughn JL, Goodwin RH, Tompkins GJ, McCawley P: The establishment of two cell lines from the insect Spodoptera frugiperda (Lepidoptera; Noctuidae). In Vitro 1977, 13(4):213-217.

4. Morillo F, Notz A: Resistance of Spodoptera frugiperda (Smith) (Lepidoptera: Noctuidae) to lambdacyhalothrin and methomyl. Entomotropica 200I, 16(2):79-87.

5. Yu SJ, Nguyen SN, Abo-Elghar GE: Biochemical characteristics of insecticide resistance in the fall armyworm, Spodoptera frugiperda (J.E. Smith). Pesticide Biochemistry and Physiology 2003, 77(I): $1-11$.

6. Simón O, Williams T, López-Ferber M, Caballero P: Genetic structure of a Spodoptera frugiperda nucleopolyhedrovirus population: High prevalence of deletion genotypes. Applied and Environmental Microbiology 2004, 10(9):5579-5588.

7. Martinez T, Fabrias G, Camps F: Sex pheromone biosynthetic pathway in Spodoptera littoralis and its activation by a neurohormone. J Biol Chem 1990, 265(3): I 38I-1387.

8. Sadek MM, Hansson BS, Rospars JP, Anton S: Glomerular representation of plant volatiles and sex pheromone components in the antennal lobe of the female Spodoptera littoralis. J Exp Biol 2002, 205(Pt I0): 1363-1376.

9. Iglesias F, Marco P, Francois MC, Camps F, Fabriàs G, Jacquin-Joly E: A new member of the PBAN family in Spodoptera littoralis: molecular cloning and immunovisualisation in scotophase hemolymph. Insect Biochemistry and Molecular Biology 2002, 32(8): $901-908$.

10. El-Mergawy R, Li Y, El-Sheikh M, El-Sayed M, Abol-Ela S, Bergoin M, Tijssen P, Fediere G: Epidemiology and biodiversity of the densovirus MIDNV in the field populations of Spodoptera littoralis and other noctuid pests. Bulletin of Faculty of Agriculture, Cairo University 2003, 54(2):269-281.

1I. Adams MD, Celniker SE, Holt RA, Evans CA, Gocayne JD, Amanatides PG, Scherer SE, Li PW, Hoskins RA, Galle RF, George RA, Lewis SE, Richards S, Ashburner M, Henderson SN, Sutton GG, Wortman JR, Yandell MD, Zhang Q, Chen LX, Brandon RC, Rogers YH, Blazej RG, Champe M, Pfeiffer BD, Wan KH, Doyle C, Baxter EG, Helt G, Nelson CR, Gabor Miklos GL, Abril JF, Agbayani A, An HJ, AndrewsPfannkoch C, Baldwin D, Ballew RM, Basu A, Baxendale J, Bayraktar- 
oglu L, Beasley EM, Beeson KY, Benos PV, Berman BP, Bhandari D, Bolshakov S, Borkova D, Botchan MR, Bouck J, Brokstein P, Brottier P, Burtis KC, Busam DA, Butler H, Cadieu E, Center A, Chandra I, Cherry JM, Cawley S, Dahlke C, Davenport LB, Davies P, de Pablos B, Delcher A, Deng Z, Mays AD, Dew I, Dietz SM, Dodson K, Doup LE, Downes M, Dugan-Rocha S, Dunkov BC, Dunn P, Durbin KJ, Evangelista CC, Ferraz C, Ferriera S, Fleischmann W, Fosler C, Gabrielian AE, Garg NS, Gelbart WM, Glasser K, Glodek A, Gong F, Gorrell JH, Gu Z, Guan P, Harris M, Harris NL, Harvey D, Heiman TJ, Hernandez JR, Houck J, Hostin D, Houston KA, Howland TJ, Wei MH, Ibegwam C, Jalali M, Kalush F, Karpen GH, Ke Z, Kennison JA, Ketchum KA, Kimmel BE, Kodira CD, Kraft C, Kravitz S, Kulp D, Lai Z, Lasko P, Lei Y, Levitsky AA, Li J, Li Z, Liang Y, Lin X, Liu X, Mattei B, Mclntosh TC, McLeod MP, McPherson D, Merkulov G, Milshina NV, Mobarry C, Morris J, Moshrefi A, Mount SM, Moy M, Murphy B, Murphy L, Muzny DM, Nelson DL, Nelson DR, Nelson KA, Nixon K, Nusskern DR, Pacleb JM, Palazzolo M, Pittman GS, Pan S, Pollard J, Puri V, Reese MG, Reinert K, Remington K, Saunders RD, Scheeler F, Shen H, Shue BC, Siden-Kiamos I, Simpson M, Skupski MP, Smith T, Spier E, Spradling AC, Stapleton M, Strong R, Sun E, Svirskas R, Tector C, Turner R, Venter E, Wang AH, Wang X, Wang ZY, Wassarman DA, Weinstock GM, Weissenbach J, Williams SM, Woodage T, Worley KC, Wu D, Yang S, Yao QA, Ye J, Yeh RF, Zaveri JS, Zhan M, Zhang G, Zhao Q, Zheng L, Zheng XH, Zhong FN, Zhong W, Zhou X, Zhu S, Zhu X, Smith HO, Gibbs RA, Myers EW, Rubin GM, Venter JC: The genome sequence of Drosophila melanogaster. Science 2000, 287(546 I):2185-2195.

12. Holt RA, Subramanian GM, Halpern A, Sutton GG, Charlab R, Nusskern DR, Wincker P, Clark AG, Ribeiro JM, Wides R, Salzberg SL, Loftus B, Yandell M, Majoros WH, Rusch DB, Lai Z, Kraft CL, Abril JF, Anthouard V, Arensburger P, Atkinson PW, Baden H, de Berardinis V, Baldwin D, Benes V, Biedler J, Blass C, Bolanos R, Boscus D, Barnstead M, Cai S, Center A, Chaturverdi K, Christophides GK, Chrystal MA, Clamp M, Cravchik A, Curwen V, Dana A, Delcher A, Dew I, Evans CA, Flanigan M, Grundschober-Freimoser A, Friedli L, Gu Z, Guan P, Guigo R, Hillenmeyer ME, Hladun SL, Hogan JR, Hong YS, Hoover J, Jaillon O, Ke Z, Kodira C, Kokoza E, Koutsos A, Letunic I, Levitsky A, Liang Y, Lin JJ, Lobo NF, Lopez JR, Malek JA, Mclntosh TC, Meister S, Miller J, Mobarry C, Mongin E, Murphy SD, O'Brochta DA, Pfannkoch C, Qi R, Regier MA, Remington K, Shao H, Sharakhova MV, Sitter CD, Shetty J, Smith TJ, Strong R, Sun J, Thomasova D, Ton LQ, Topalis $P$, Tu Z, Unger MF, Walenz B, Wang A, Wang J, Wang M, Wang X, Woodford KJ, Wortman JR, Wu M, Yao A, Zdobnov EM, Zhang H, Zhao Q, Zhao S, Zhu SC, Zhimulev I, Coluzzi M, della Torre A, Roth CW, Louis C, Kalush F, Mural RJ, Myers EW, Adams MD, Smith HO, Broder S, Gardner MJ, Fraser CM, Birney E, Bork P, Brey PT, Venter JC, Weissenbach J, Kafatos FC, Collins FH, Hoffman SL: The genome sequence of the malaria mosquito Anopheles gambiae. Science 2002, 298(559 I): I29-149.

13. [http://www.hgsc.bcm.tmc.edu/projects/honeybee/].

14. Mita K, Kasahara M, Sasaki S, Nagayasu Y, Yamada T, Kanamori H, Namiki N, Kitagawa M, Yamashita H, Yasukochi Y, Kadono-Okuda $K$, Yamamoto K, Ajimura M, Ravikumar G, Shimomura M, Nagamura Y, Shin IT, Abe H, Shimada T, Morishita S, Sasaki T: The genome sequence of silkworm, Bombyx mori. DNA Res 2004, I I(I):27-35.

15. Xia Q, Zhou Z, Lu C, Cheng D, Dai F, Li B, Zhao P, Zha X, Cheng T, Chai C, Pan G, Xu J, Liu C, Lin Y, Qian J, Hou Y, Wu Z, Li G, Pan M, Li C, Shen Y, Lan X, Yuan L, Li T, Xu H, Yang G, Wan Y, Zhu Y, Yu M, Shen W, Wu D, Xiang Z, Yu J, Wang J, Li R, Shi J, Li H, Li G, Su J, Wang X, Li G, Zhang Z, Wu O, Li J, Zhang O, Wei N, Xu J, Sun H, Dong L, Liu D, Zhao S, Zhao X, Meng Q, Lan F, Huang X, Li Y, Fang L, Li C, Li D, Sun Y, Zhang Z, Yang Z, Huang Y, Xi Y, Qi Q, He D, Huang H, Zhang X, Wang Z, Li W, Cao Y, Yu Y, Yu H, Li J, Ye J, Chen $\mathrm{H}$, Zhou Y, Liu B, Wang J, Ye J, Ji H, Li S, Ni P, Zhang J, Zhang Y, Zheng H, Mao B, Wang W, Ye C, Li S, Wang J, Wong GK, Yang H: A draft sequence for the genome of the domesticated silkworm (Bombyx mori). Science 2004, 306(5703): 1937-1940.

16. [http://www.ab.a.u-tokyo.ac.jp/lep-genome].

17. Wang J, Xia Q, He X, Dai M, Ruan J, Chen J, Yu G, Yuan H, Hu Y, Li R, Feng T, Ye C, Lu C, Wang J, Li S, Wong GK, Yang H, Wang J, Xiang Z, Zhou Z, Yu J: SilkDB: a knowledgebase for silkworm biology and genomics. Nucleic Acids Res 2005, 33(Database):D399-402.

18. [http://pestgenomics.org/overview.htm].
19. Papanicolaou A, Joron M, McMillan WO, Blaxter ML, Jiggins CD: Genomic tools and cDNA derived markers for butterflies. Mol Ecol 2005, I 4(9):2883-2897.

20. [http://heliconius.cap.ed.ac.uk/butterfly/db/].

21. Boguski MS, Lowe TM, Tolstoshev CM: dbEST-database for "expressed sequence tags". Nat Genet 1993, 4(4):332-3.

22. d'Alençon E, Piffanelli P, Volkoff AN, Sabau X, Gimenez S, Rocher J, Cérutti P, Fournier P: A genomic BAC library and a new BACGFP vector to study the holocentric pest Spodoptera frugiperda. Insect Biochemistry and Molecular Biology 2004, 34(4):33I-34I.

23. Landais I, Ogliastro M, Mita K, Nohata J, López-Ferber M, DuonorCérutti M, Shimada T, Fournier P, Devauchelle G: Annotation pattern of ESTs from Spodoptera frugiperda Sf9 cells and analysis of the ribosomal protein genes reveal insect-specific features and unexpectedly low codon usage bias. Bioinformatics 2003, 19(1 8):2343-2350.

24. Ewing B, Green P: Base-calling of automated sequencer traces using phred. II. Error probabilities. Genome Res 1998, 8(3): $186-194$.

25. Ewing B, Hillier L, WendI MC, Green P: Base-calling of automated sequencer traces using phred. I. Accuracy assessment. Genome Res 1998, 8(3): 175-185

26. Altschul SF, Gish W, Miller W, Myers EW, Lipman DJ: Basic local alignment search tool. J Mol Biol I990, 2I 5(3):403-4I0.

27. Pertea G, Huang $X$, Liang $F$, Antonescu V, Sultana R, Karamycheva $S$, Lee Y, White J, Cheung F, Parvizi B, Tsai J, Quackenbush J: TIGR Gene Indices clustering tools (TGICL): a software system for fast clustering of large EST datasets. Bioinformatics 2003, 19(5):65I-652.

28. Iseli C, Jongeneel CV, Bucher P: ESTScan: a program for detecting, evaluating, and reconstructing potential coding regions in EST sequences. Proc Int Conf Intell Syst Mol Biol 1999: I38-48.

29. Whiting MF: Phylogeny of the holometabolous insect orders: molecular evidence. Zoologica Scripta 2002, 3I(I):3-I5.

30. Merritt TJS, LaForest S, Prestwihc GD, Quattro JM, Vogt RG: Patterns of gene duplication in lepidopteran pheromone binding proteins. J Mol Evol 1998, 46:272-276.

31. Minet J: Tentative reconstruction of the ditrysian phylogeny (Lepidoptera: Glossata). Entomologica Scandinavica 1991, 22(I):69-95.

32. Gaunt MW, Miles MA: An insect molecular clock dates the origin of the insects and accords with paleontological and biogeographic landmarks. Mol Biol Evol 2002, 19(5):748-76I.

33. Apweiler R, Bairoch A, Wu CH, Barker WC, Boeckmann B, Ferro S, Gasteiger E, Huang H, Lopez R, Magrane M, Martin MJ, Natale DA, O'Donovan C, Redaschi N, Yeh LS: UniProt: the Universal Protein knowledgebase. Nucleic Acids Res 2004, 32(Database):DII5-II9.

34. Gene Ontology Consortium: The Gene Ontology (GO) project in 2006. Nucleic Acids Res 34(Database):D322-6. 2006 Jan I

35. Camon E, Magrane M, Barrell D, Lee V, Dimmer E, Maslen J, Binns D, Harte N, Lopez R, Apweiler R: The Gene Ontology Annotation (GOA) Database : sharing knowledge in Uniprot with Gene Ontology. Nucleic Acids Res 32(Database):D262-6. 2004 Jan I

36. [http://www.acedb.org].

37. Harris TW, Lee R, Schwarz E, Bradnam K, Lawson D, Chen W, Blasier D, Kenny E, Cunningham F, Kishore R, Chan J, Muller HM, Petcherski A, Thorisson G, Day A, Bieri T, Rogers A, Chen CK, Spieth J, Sternberg P, Durbin R, Stein LD: WormBase: a cross-species database for comparative genomics. Nucleic Acids Res 2003, 3 I(I): I33-137.

38. Dicks J, Anderson M, Cardle L, Cartinhour S, Couchman M, Davenport G, Dickson J, Gale M, Marshall D, May S, McWilliam H, O'Malia A, Ougham H, Trick M, Walsh S, Waugh R: UK CropNet: a collection of databases and bioinformatics resources for crop plant genomics. Nucleic Acids Res 2000, 28(I): I04-107.

39. Martin SL, Blackmon BP, Rajagopalan R, Houfek TD, Sceeles RG, Denn SO, Mitchell TK, Brown DE, Wing RA, Dean RA: MagnaportheDB: a federated solution for integrating physical and genetic map data with BAC end derived sequences for the rice blast fungus Magnaporthe grisea. Nucleic Acids Res 2002, 30(1): $12 \mid-124$

40. Cousin X, Hotelier T, Giles K, Toutant JP, Chatonnet A: aCHEdb: the database system for ESTHER, the alpha/beta fold family 
of proteins and the Cholinesterase gene server. Nucleic Acids Res 1998, 26(I):226-228.

41. Leveugle M, Prat K, Perrier N, Birnbaum D, Coulier F: ParaDB: a tool for paralogy mapping in vertebrate genomes. Nucleic Acids Res 2003, 3 I (1):63-67.

42. Ruiz M, Rouard M, Raboin LM, Lartaud M, Lagoda P, Courtois B: TropGENE-DB, a multi-tropical crop information system. Nucleic Acids Res 2004, 32(Database):D364-367.

43. Stein LD, Thierry-Mieg J: Scriptable access to the Caenorhabditis elegan s genome sequence and other ACEDB databases. Genome Res 1998, 8(12): |308-1315.

44. Mitchell A, Mitter C, Regier JC: Systematics and evolution of the cutworm moths (Lepidoptera: Noctuidae): evidence from two protein-coding nuclear genes. Systematic Entomology 2006, 3I:2I-46.

Publish with Bio Med Central and every scientist can read your work free of charge

"BioMed Central will be the most significant development for disseminating the results of biomedical research in our lifetime. "

Sir Paul Nurse, Cancer Research UK

Your research papers will be:

- available free of charge to the entire biomedical community

- peer reviewed and published immediately upon acceptance

- cited in PubMed and archived on PubMed Central

- yours - you keep the copyright

Submit your manuscript here:

http://www.biomedcentral.com/info/publishing_adv.asp
BiolMedcentral 